\title{
Comparison of the pregnancy outcomes of the patients with severe symptoms who received medical treatment for COVID-19 versus the patients with mild-moderate symptoms
}

\author{
Semra Yüksel ${ }^{1}$ (D) , Güray Tuna² (iD) , Fatma Ketenci Gencer ${ }^{3}$ (ID) , \\ Hatice Yaşat Nacar ${ }^{3}$ (ID), Süleyman Salman ${ }^{3}$ \\ ${ }^{1}$ Department of Obstetrics and Gynecology, Başakşehir Çam and Sakura City Hospital, İstanbul, Turkey \\ ${ }^{2}$ Division of Perinatology, Department of Obstetrics and Gynecology, Başakşebir Çam and Sakura City Hospital, İstanbul, Turkey \\ ${ }^{3}$ Department of Obstetrics and Gynecology, Gaziosmanpassa Training and Research Hospital, Istanbul, Turkey
}

\begin{abstract}
Objective: COVID-19 has spread all over the world since December 2019. There is little evidence concerning maternal or perinatal outcomes up to now. The present study aimed to compare pregnant women with severe and mild-moderate COVID-19 symptoms in terms of maternal and perinatal outcomes.

Methods: The study group was composed of pregnant patients admitted to our tertiary center with symptoms and diagnosed with severe acute respiratory syndrome Coronavirus 2 (SARS-Cov-2). The patients were categorized into two groups: severe and not severe, and women determined as in the severe disease group were hospitalized. The patients were continued to their routine follow-up, their maternal and perinatal outcomes were recorded.

Results: A total of 52 patients were enrolled in the study: $59.6 \%$ presented mild-moderate disease and $40.4 \%$ presented severe disease. The gestational age at diagnosis of COVID-19 was higher in the patients with severe symptoms than in patients with mild-moderate symptoms (median 20.5 vs 28.0 , respectively, $\mathrm{p}=0.048$ ). There was no difference between those two groups in terms of maternal and perinatal outcomes. Conclusion: Despite the growing number of published studies on COVID-19 in pregnancy, there are insufficient quality data to draw conclusions about the severity of COVID-19 in symptomatic pregnant women and its maternal and neonatal consequences. In our study, there is no difference between mild-moderate and severe groups in terms of maternal and perinatal outcomes.
\end{abstract}

Keywords: COVID-19, COVID-19 in pregnancy, COVID-19 with severe symptoms.
Özet: COVID-19 için tıbbi tedavi gören ve şiddetli semptomları olan hastalar ile hafif semptomları olan hastaların gebelik sonuçlarının karşılaştırılması

Amaç: Aralık 2019'dan bu yana COVID-19 tüm dünyaya yayıldı. Şu ana kadar maternal veya perinatal sonuçlarla ilgili olarak elimizde çok az kanıt bulunmaktadır. Bu çalışmada, şiddetli ve hafif-orta şiddette COVID-19 semptomları olan gebeleri maternal ve perinatal sonuçlar bakımından karşılaştırmayı amaçladık.

Yöntem: Çalışma grubu, şiddetli akut respiratuvar sendrom Koronavirüs 2 (SARS-Cov-2) semptomlarılya üçüncü basamak merkezimize başvuran ve tanı almış gebelerden oluştu. Hastalar şiddetli ve şiddetli olmayan şeklinde iki gruba ayrıldı ve şiddetli hastalık grubunda olduğuna karar verilen gebeler hastaneye yatırldı. Hastaların rutin takiplerine devam edilerek maternal ve perinatal sonuçları kaydedildi.

Bulgular: Çalışmaya toplam 52 hasta dahil edildi, bunların $\% 59.6$ 'snda hafif-orta şiddette ve \% 40.4 'ünde şiddetli hastalı mevcuttu. COVID-19 tanısı esnasında gestasyonel yaş, şiddetli semptomları olan hastalarda hafif-orta şiddette semptomu olan hastalardan daha yüksekti (sırasıyla medyan: 20.5'e karşı 28.0, $\mathrm{p}=0.048$ ). Maternal ve perinatal sonuçlar yönünden bu iki grup arasında hiçbir fark yoktu.

Sonuç: Gebelikte COVID-19 üzerine artan sayıda yayınlanmış çalışmaya rağmen, semptomatik gebelerde COVID-19'un şiddeti ve maternal ve neonatal sonuçları hakkında sonuç çıkarmaya yetecek miktarda kaliteli veri bulunmamaktadır. Çalışmamızda, hafiforta şiddette semptomlu grup ile şiddetli semptomlu grup arasında maternal ve perinatal sonuçlar yönünden fark yoktu.

Anahtar sözcükler: COVID-19, gebelikte COVID-19, şiddetli semptomlarla COVID-19.

Correspondence: Semra Yüksel, MD. Department of Obstetrics and Gynecology, Başakşehir Çam and Sakura City Hospital, İstanbul, Turkey. e-mail: drsemrayuksel@gmail.com / Received: April 19, 2021; Accepted: July 27, 2021

How to cite this article: Yüksel S, Tuna G, Ketenci Gencer F, Yaşat Nacar H, Salman S. Comparison of the pregnancy outcomes of the patients with severe symptoms who received medical treatment for COVID-19 versus the patients with mild-moderate symptoms. Perinatal Journal 2021;29(2):120-125. doi: $10.2399 /$ prn.21.0292007

ORCID ID: S. Yüksel 0000-0003-3773-4107; G. Tuna 0000-0003-0423-3760; F. Ketenci Gencer 0000-0002-6076-2563; 


\section{Introduction}

The COVID-19 pandemic, which is thought to arose from Wuhan in China in December of 2019, has a great potential to cause severe and acute respiratory distress diseases. Governments around the world took strict measures to prevent the spread of the disease. ${ }^{[1]}$ As one of these measures, the International Federation of Gynecology and Obstetrics (FIGO), American College of Obstetricians and Gynecologists (ACOG), and Royal College of Obstetricians and Gynaecologists (RCOG) recommended less frequent antenatal care visits to reduce transmission of the virus to pregnant women. Furthermore, telephone or video-based consultation was also recommended in low-risk pregnancies rather than in-person meetings. ${ }^{[2]}$

Two previous Coronavirus infections (SARS-CoV, MERS-CoV) in pregnancy showed that the pregnant women infected with these two viruses were more prone to need intensive care unit hospitalization, endotracheal intubation, and develop renal failure. ${ }^{[3]}$ In pregnant women diagnosed with COVID-19, the most common presenting symptoms are non-productive cough, shortness of breath, tiredness, and diarrhea rather than fever, one of the most common symptoms of non-pregnant patients. ${ }^{[4,5]}$ During the pandemic, in cases of high-risk pregnancies, women were more prone to present disease morbidity after COVID-19. The need for mechanical ventilation in pregnant women was slightly less common when compared to SARS-CoV and MERS-CoV outbreaks. ${ }^{[4,6]}$

However, not only the mother but the fetus is also susceptible to viral infection. Infected newborns generally present mild lymphocytopenia with mild findings of pneumonia. The mode of transmission, whether vertical or horizontal by aerosols, is still unclear. ${ }^{[7]}$ The mode of delivery should be decided according to the patient's medical status concerning comorbidities and obstetric and fetal conditions. Babies born to suspected or confirmed COVID-19 women were recommended to be examined carefully, even when there were no signs of COVID-19 infection. ${ }^{[5]}$

Treatment of a pregnant patient with confirmed COVID-19 infection is another confusing topic because there is still no proven effective and safe drug in pregnancy. For antiviral therapy, chloroquine, azithromycin, lopinavir, and remdesivir are the drugs that were tried in pregnancy and lopinavir is the only drug reported to reduce mortality. ${ }^{[8]}$ In addition, thromboprophylaxis is recommended because pregnancy tends to cause a procoagulative state.

There is still a clinical lack of data in the literature regarding the effect of COVID-19 infection during pregnancy on maternal and perinatal outcomes. In this study, we aimed to compare the pregnancy outcomes of the patients with severe symptoms who received medical treatment and the patients with mild-moderate symptoms of COVID-19.

\section{Methods}

This retrospective cohort study included pregnant patients who had a routine follow-up in our out-patient clinic between March 1 and October 2020. The women who had symptomatic COVID-19 disease with a positive real-time reverse-transcription polymerase chain reaction (RT-PCR) assay of nasopharyngeal and oropharyngeal swab specimens during pregnancy were enrolled in this study. The patients who did not come to our clinic for follow-up were excluded from the study. The institutional review board of Training and Research Hospital and the Turkish Ministry of Health approved this study (Institutional review board [IRB] ID no:163, 2020; 202006-13T12_24_58, respectively).

The demographic and clinical data of the patients were obtained from the electronic medical records and archive files. The maternal age, gestational age at COVID-19 infection, body mass index (BMI), symptoms, medical treatment for COVID-19, obstetric complications during pregnancy, and neonatal outcomes were recorded. SARS$\mathrm{CoV}-2$ infection severity was categorized as severe and mild-moderate. Mild symptoms were described as upper respiratory congestion, headache, gastrointestinal symptoms, and myalgia. Severe symptoms were described as chest pain, dyspnea or low oxygen saturation $\left(\mathrm{s}_{2}<92 \%\right)$. The hospitalization criteria were determined as the pregnant patients with severe symptoms, body mass index (BMI) $>30 \mathrm{~kg} / \mathrm{m}^{2}$, gestational diabetes mellitus (DM), pregestational DM, chronic hypertension, preeclampsia, maternal age $>35$, high risk of venous thromboembolism, lymphopenia, and increasing levels of inflammatory markers including CRP, ferritin, and procalcitonin. The patients with pneumonia were treated with hydroxychloroquine and/or lopinavir/ritonavir. ${ }^{[9]}$

Statistical analysis was performed with SPSS version 23 (IBM Corp., Armonk, NY, USA). Categorical variables are displayed as numbers and percentages, while continuous variables are displayed as means $( \pm$ standard 
Table 1. Demographic characteristics of the patients with mild-moderate and severe symptoms of Covid-19.

\begin{tabular}{lccc} 
& $\begin{array}{c}\text { Patients with mild-moderate } \\
\text { symptoms (n=31) }\end{array}$ & $\begin{array}{c}\text { Patients with severe symptoms who } \\
\text { received medical treatment (n=21) }\end{array}$ & $\begin{array}{c}\text { p-value } \\
\text { Age }\end{array}$ \\
\hline Gravida & $28.0 \pm 5.3$ & $30.0 \pm 6.2$ & $0.22^{*}$ \\
\hline Parity & $3.0(1-5)$ & $3(1-10)$ & $0.37^{*}$ \\
\hline BMl & $1(0-4)$ & $1(0-4)$ & $0.86^{*}$ \\
\hline Smoking & $28.6 \pm 5.6$ & $30.6 \pm 5.9$ & $0.26^{*}$ \\
\hline Gestational age at diagnosis (weeks) & $4(\% 12.9)$ & $1(\% 4.8)$ & $0.64^{+}$ \\
\hline Fever & $20.5(4.0-39.2)$ & $28.0(4.0-38.1)$ & $0.048^{*}$ \\
\hline Cough & $8(\% 28.6)$ & $2(\% 9.5)$ & $0.16^{+}$ \\
\hline Myalgia & $17(\% 60.7)$ & $13(\% 61.9)$ & $0.93^{\ddagger}$ \\
\hline Absent taste & $20(\% 64.5)$ & $14(\% 66.7)$ & $0.87^{\ddagger}$ \\
\hline Dyspnea & $13(\% 41.9)$ & $3(\% 14.3)$ & $0.064^{\dagger}$ \\
\hline Hospital stay after birth (days) & $1(\% 3.2)$ & $4(\% 19.0)$ & $0.15^{+}$ \\
\hline
\end{tabular}

*Mann-Whitney U test; †Fisher's exact test; $¥$ Pearson chi-square test.

deviation) or medians (interquartile ranges [IQRs]), depending on the normality of each distribution. Comparison of the patients with severe and mild-moderate patients was performed with chi-square test, Fisher's exact test or Mann-Whitney U-test. A p-value of $<0.05$ was considered statistically significant.

\section{Results}

A total of 62 pregnant patients were admitted to the outpatient clinic at our center who had symptomatic COVID-19 infection during pregnancy. 2 patients were lost to follow up so excluded from the study. The gestational age of the 8 patients was at 30-35 weeks when the study was ended, so they were excluded from the study. Total 52 pregnant patients who had symptomatic COVID-19 infection during their pregnancy were enrolled in this study. The demographic characteristics of the patients are shown in Table 1. The mean maternal age of the pregnant patients was 28.8 \pm 5.7. Trimester at diagnosis of COVID-19: first trimester, 14 patients, 26.9\%; second trimester, 23 patients, $44.2 \%$, and third trimester, 15 patients, $28.8 \%$. Distribution of the patients according to trimester was shown in Table 2 . There was no difference among the groups in terms of age, parity, BMI, symptoms, gestational age at birth. Gestational age at diagnosis of COVID-19 was higher in the severe patient group than in the mild-moderate group $(\mathrm{p}=0.048)$.
The patients who had severe symptoms (dyspnea, low oxygen saturation) were hospitalized (21 patients, $40.4 \%$ ). Hydroxychloroquine 13.5\%, lopinavir/ritonavir $17.3 \%$, hydroxychloroquine+ lopinavir/ritonavir $3.5 \%$, and azithromycin 5.8\% were used for COVID-19 treatment.

Perinatal complications of two patient groups were shown in Table 3. Most of the patients in both groups had no complications during pregnancy $(83.9 \%$ vs $85.7 \%)$. Preeclampsia and preterm birth were seen only in patients with mild-moderate symptoms. There was no difference between the two groups regarding gestational age at birth, birth weight, and neonatal intensive care unit (NICU) admission (Table 4).

\section{Discussion}

The course of COVID-19 in pregnancy and maternal and perinatal outcomes has not been elucidated so far. Symptomatic women had a significantly increased risk of severe disease compared to non-pregnant women

Table 2. Distribution of the patients with mild-moderate and severe symptoms according to trimester at diagnosis of COVID-19.

\begin{tabular}{lcc} 
Trimester at diagnosis & $\begin{array}{c}\text { Patients with } \\
\text { mild-moderate } \\
\text { symptoms (n, \%) }\end{array}$ & $\begin{array}{c}\text { Patients with } \\
\text { severe symptoms } \\
(\mathbf{n}, \%)\end{array}$ \\
\hline First trimester & $10(32.3 \%)$ & $4(19 \%)$ \\
\hline Second trimester & $17(54.8 \%)$ & $6(28.6 \%)$ \\
\hline Third trimester & $4(12.9 \%)$ & $11(52.4 \%)$ \\
\hline
\end{tabular}


Table 3. Perinatal complications of the patients with mild-moderate and severe symptoms of COVID-19.

\begin{tabular}{|c|c|c|c|}
\hline & $\begin{array}{l}\text { Patients with mild-moderate } \\
\text { symptoms }(n=31)\end{array}$ & $\begin{array}{l}\text { Patients with severe symptoms who } \\
\text { received medical treatment }(n=21)\end{array}$ & p-value* \\
\hline No pregnancy complication & 26 (83.9\%) & $18(85.7 \%)$ & 0.59 \\
\hline Preeclampsia & $2(6.5 \%)$ & - & \\
\hline Preterm birth & $1(3.2 \%)$ & - & \\
\hline PPROM & $1(3.2 \%)$ & $1(4.8 \%)$ & 0.65 \\
\hline GDM & $1(3.2 \%)$ & $1(4.8 \%)$ & 0.65 \\
\hline TPB & - & $1(4.8 \%)$ & \\
\hline SGA & 1 (3.2\%) & & \\
\hline
\end{tabular}

*Mann-Whitney U test. GDM: gestational diabetes mellitus; PPROM: preterm premature rupture of the membranes; SGA: small for gestational age; TPB: threatened preterm birth.

due to the altered immune system during pregnancy. ${ }^{[10]}$ In this study, we investigated symptomatic pregnant women who had mild-moderate and severe COVID19 infection during pregnancy. We found gestational age at diagnosis of COVID-19 was higher in the severe patient group than the mild-moderate group $(\mathrm{p}=0.048)$ and there was no difference regarding pregnancy and neonatal outcomes between the severe and non-severe groups. Although a high number of COVID-19 during pregnancy were reported in Turkey, there are still few studies regarding maternal or perinatal outcomes of COVID-19 infection during pregnancy. ${ }^{[11,12]}$ The study, including 533 patients, reported that most of the pregnant women diagnosed with COVID-19 had mild symptoms $(95.5 \%)$, and only $0.5 \%$ of the cases had severe symptoms. ${ }^{[12]}$ In our study, $40.4 \%$ of the patients diagnosed with COVID-19 suffered from severe symptoms. Since our study group consists of only symptomatic patients, the proportion of those with severe illness can be expected to be high.

In a study including 1219 patients, severe-critical COVID-19 was associated with increased risk of cesarean birth (RR 1.57), hypertensive disorders of pregnancy (RR 1.61), and preterm birth (RR 3.53) compared with asymptomatic patients. Mild-moderate COVID-19 was not associated with adverse perinatal outcomes compared with asymptomatic patients. ${ }^{[13]}$ In contrast, in a population-based study as compared with non-infected women, women with symptomatic COVID-19 had increased rates of preterm delivery $(\mathrm{p}=0.003)$ and intrapartum fetal distress $(\mathrm{p}=0.004)$, while asymptomatic women had similar rates to non-infected cases. ${ }^{[14]}$ Cruz Lemini et al. reported higher premature rupture of membranes at term in the COVID group than healthy pregnant women group $(\mathrm{p}=0.015) \cdot{ }^{[15]}$ In our study, there was no difference regarding pregnancy complications between mild-moderate and severe COVID-19 groups.

We found gestational age at diagnosis of COVID-19 was higher in the severe group than mild-moderate group ( $\mathrm{p}=0.048$ ). Similar to our study, the COVID-19 disease was related to severe symptoms later in pregnancy compared to earlier weeks of gestation. ${ }^{[16]}$ However, in another study it was reported that higher gestational age was protective against COVID-19 in pregnant women. ${ }^{[17]}$ Fever, cough, lymphopenia and raised C-reactive protein levels are the most common characteristics of the severe COVID-19 disease. In the third trimester, it was known that innate immune barriers are strengthened but the

Table 4. Neonatal outcomes of the mild-moderate and severe groups of the patients.

\begin{tabular}{lcccc} 
& $\begin{array}{c}\text { Patients with mild-moderate } \\
\text { symptoms }(\mathbf{n}=31)\end{array}$ & $\begin{array}{c}\text { Patients with severe symptoms who } \\
\text { received medical treatment }(\mathbf{n}=\mathbf{2 1})\end{array}$ & $\begin{array}{c}\text { p-value } \\
\text { Gestational age at birth }\end{array}$ \\
\hline Birth weight & $38.7 \pm 1.6$ & $38.6 \pm 2.0$ & $0.90^{*}$ \\
\hline NICU & $3226 \pm 368$ & $3256 \pm 319$ & $0.77^{*}$ \\
\hline
\end{tabular}

*Mann-Whitney U test; ${ }^{\top}$ Fisher's exact test. NICU: neonatal intensive care unit. 
adaptive/inflammatory immunity is reduced. The possible causes of that increase in neutrophils and monocytes are a repression of natural killer cell peripheral number and function, a decrease in $\mathrm{T}$ and $\mathrm{B}$ cells, and an increase in dendritic cells that produce type 1 interferon (IFN), which is very important to viral response. ${ }^{[18]}$

Up to now remdesivir, lopinavir-ritonavir, interferon beta, corticosteroids, chloroquine and hydroxychloroquine, and ivermectin were used in medical treatment of COVID-19 infection. ${ }^{[19]}$ But there was no known antiviral agent specific to COVID-19 infection in pregnancy. In large proportion of the clinical trials, the pregnant patients were excluded due to concerns about teratogenicity or side effects in pregnancy. According to the Turkish Ministry of Health recommendations in Turkey, hydroxychloroquine and/or lopinavir/ritonavir, azithromycin, and low molecular weight heparin were used in pregnant patients with severe symptoms since the early days of the pandemic. ${ }^{[12]}$ In our study, we observed firstly lopinavir/ritonavir and secondly hydroxychloroquine were used for treatment. Although we had all symptomatic COVID-19 positive women, no pregnancy complication was observed in most patients $(83.9 \%$ and $85.7 \%$ in mild-moderate and severe group, respectively). According to a multinational cohort study, SARS-CoV-2 infection in pregnant women is associated with a $0.8 \%$ rate of maternal mortality and $11.1 \%$ rate of admission to the ICU. ${ }^{[20]}$ The cause of different maternal and neonatal outcomes reported from different countries may be related to different medical treatment modalities for the management of COVID-19 in pregnancy.

No significantly increased risk of pregnancy loss for women with COVID-19 infection was reported. ${ }^{[2]]} \mathrm{We}$ did not observe abortion in the follow-up of the study groups. In addition, the risk of vertical transmission after COVID-19 infection was reported as negligible. ${ }^{[20,22,23]} \mathrm{In}$ other studies, the risk of transmission from mother-toinfant was reported as $1.5-5 \%$. On the other hand, the positivity rate was not higher in infants who stayed in the same room with the mother than infants initially separated and cared for in a SARS-CoV-2-free environment. ${ }^{[24]}$ Since the time of the infection was remote from labor, we did not observe any neonatal COVID-19 infection in our study groups and the mean gestational week at birth and mean birthweight were in the normal range in our study. A study showed that severe placental infection did not increase preterm labor and delivery or NICU admissions from SARS-CoV2 positive mothers.
The hypothesis is that the placenta acts as a barrier for the fetus during viral infection. ${ }^{[23]}$

The limitations of the present study were a relatively small number of the study population. Due to lack of a population screening, the pregnancy outcomes of the COVID-19 infected patients with no symptoms or with symptoms who did not come to follow-up, were not known. Our study groups had COVID-19 infection at different trimesters of the pregnancy. We do not know if the maternal or fetal morbidities related with COVID-19 vary with gestational age. Different medical therapies were used in management of the patients with severe symptoms of COVID-19. So, we need more prospective studies, including a high number of patients, to evaluate the role of medical treatment on the prognosis of the disease and compare the pregnancy outcomes of the severe group with the mildmoderate group of the patients.

\section{Conclusion}

According to our findings, there was no difference in neonatal outcomes between the severe and mild-moderate groups of COVID-19 infected pregnant patients. The mean gestational week of the severe group that COVID-19 infection had diagnosed was higher than the mild-moderate group. Different medical therapies were used in the management of the patients with severe symptoms of COVID-19.

Funding: This work did not receive any specific grant from funding agencies in the public, commercial, or not-for-profit sectors.

Compliance with Ethical Standards: The authors stated that the standards regarding research and publication ethics, the Personal Data Protection Law and the copyright regulations applicable to intellectual and artistic works are complied with and there is no conflict of interest.

\section{References}

1. Wastnedge EAN, Reynolds RM, van Boeckel SR, Stock SJ, Denison FC, Maybin JA, et al. Pregnancy and COVID-19. Physiol Rev 2021;101:303-18. [PubMed] [CrossRef]

2. Poon LC, Yang H, Kapur A, Melamed N, Dao B, Divakar H, et al. Global interim guidance on coronavirus disease 2019 (COVID-19) during pregnancy and puerperium from FIGO and allied partners: information for healthcare professionals. Int J Gynaecol Obstet 2020;149:273-86. [PubMed] [CrossRef]

3. Juan J, Gil MM, Rong Z, Zhang Y, Yang H, Poon LC. Effect of coronavirus disease 2019 (COVID-19) on maternal, perinatal and neonatal outcome: systematic review. Ultrasound Obstet Gynecol 2020;56:15-27. [PubMed] [CrossRef] 
4. Zaigham M, Andersson O. Maternal and perinatal outcomes with COVID-19: a systematic review of 108 pregnancies. Acta Obstet Gynecol Scand 2020;99:823-9. [PubMed] [CrossRef]

5. Wenling Y, Junchao Q, Xiao Z, Ouyang S. Pregnancy and COVID-19: management and challenges. Rev Inst Med Trop Sao Paulo 2020;62:e62. [PubMed] [CrossRef]

6. Di Mascio D, Khalil A, Saccone G, Rizzo G, Buca D, Liberati $\mathrm{M}$, et al. Outcome od coronavirus spectrum infections (SARS, MERS, COVID-19) during pregnancy: a systematic review and meta-analysis. Am J Obstet Gynecol MFM 2020;2:100107. [PubMed] [CrossRef]

7. Zeng L, Xia S, Yuan W, Yan K, Xiao F, Shao J, et al. Neonatal early-onset infection with SARS-CoV-2 in 33 neonates born to mothers with COVID-19 in Wuhan, China. JAMA Pediatr 2020;174:722-5. [PubMed] [CrossRef]

8. Narang K, Enninga EAL, Gunaratne MDSK, Ibirogba ER, Trad ATA, Elrefaei A, et al. SARS-CoV-2 Infection and COVID-19 during pregnancy: a multidisciplinary review. Mayo Clin Proc 2020;95:1750-65. [PubMed] [CrossRef]

9. Republic of Turkey Ministry of Health. The recommendations of the Scientific Comitttee regarding pregnant women followup during respiratory infections [Internet]. [Document in Turkish] Ankara: Republic of Turkey Ministry of Health [cited 2020 Oct 16]. Available from: https://covid19.saglik.gov.tr/ Eklenti/39101/0/covid-19solunumsistemihastaliklarininyayginoldugudonemdesaglikkuruluslarindagebetakibipdf.pdf

10. Oakes MC, Kernberg AS, Carter EB, Foeller ME, Palanisamy A, Raghuraman N, et al. Pregnancy as a risk factor for severe coronavirus disease 2019 using standardized clinical criteria. Am J Obstet Gynecol MFM 2021;3(3):100319. [PubMed] [CrossRef]

11. Ozsurmeli M, Terzi H, Hocaoglu M, Bilir RA, Gunay T, Unsal $\mathrm{D}$, et al. Clinical characteristics, maternal and neonatal outcomes of pregnant women with SARS-CoV-2 infection in Turkey. Bratisl Lek Listy 2021;122:152-7. [PubMed] [CrossRef]

12. Sahin D, Tanacan A, Erol SA, Anuk AT, Eyi EGY, OzguErdinc AS, et al. A pandemic center's experience of managing pregnant women with COVID-19 infection in Turkey: a prospective cohort study. Int J Gynaecol Obstet 202;151:7482. [PubMed] [CrossRef]

13. Metz TD, Clifton RG, Hughes BL, Sandoval G, Saade GR, Grobman WA, et al.; Eunice Kennedy Shriver National Institute of Child Health and Human Development (NICHD) Maternal-Fetal Medicine Units (MFMU) Network. Disease severity and perinatal outcomes of pregnant patients with coronavirus disease 2019 (COVID-19). Obstet Gynecol 2021;137: 571-80. [PubMed] [CrossRef]
14. Crovetto F, Crispi F, Llurba E, Pascal R, Larroya M, Trilla C, et al. Corona Pregnancy COVID-19 Group. Impact of SARSCoV-2 infection on pregnancy outcomes: a population-based study. Clin Infect Dis 2021:ciab104. [PubMed] [CrossRef]

15. Cruz-Lemini M, Ferriols Perez E, de la Cruz Conty ML, Caño Aguilar A, Encinas Pardilla MB, Prats Rodríguez P, et al.; On Behalf of The Spanish Obstetric Emergency Group. Obstetric outcomes of SARS-CoV-2 infection in asymptomatic pregnant women. Viruses 2021;13:112. [PubMed] [CrossRef]

16. Berry M, Wang A, Clark SM, Harirah HM, Jain S, Olson GL, et al. Clinical stratification of pregnant COVID-19 patients based on severity: a single academic center experience. Am J Perinatol 2021;38:515-22. [PubMed] [CrossRef]

17. Tutiya C, Mello F, Chaccur G, Almeida C, Galvão E, Barbosa de Souza AC, et al. Risk factors for severe and critical Covid19 in pregnant women in a single center in Brazil. J Matern Fetal Neonatal Med 2021 Feb 3:1-4. Online ahead of print. [PubMed] [CrossRef]

18. Kraus TA, Engel SM, Sperling RS, Kellerman L, Lo Y, Wallenstein $\mathrm{S}$, et al. Characterizing the pregnancy immune phenotype: results of the viral immunity and pregnancy (VIP) study. J Clin Immunol 2012;32:300-11. [PubMed] [CrossRef]

19. Taylor MM, Kobeissi L, Kim C, Amin A, Thorson AE, Bellare $\mathrm{NB}$, et al. Inclusion of pregnant women in COVID-19 treatment trials: a review and global call to action. Lancet Glob Health 2021;9:e366-e371. [PubMed] [CrossRef]

20. WAPM (World Association of Perinatal Medicine) Working Group on COVID-19. Maternal and perinatal outcomes of pregnant women with SARS-CoV-2 infection. Ultrasound Obstet Gynecol 2021;57:232-41. [PubMed] [CrossRef]

21. la Cour Freiesleben N, Egerup P, Hviid KVR, Severinsen ER, Kolte AM, Westergaard D, et al. SARS-CoV-2 in first trimester pregnancy: a cohort study. Hum Reprod 2021;36: 40-7. [PubMed] [CrossRef]

22. Guo Y, Yuan J, Wang M, Yu Y, Bian J, Fan C. Case series of 20 pregnant women with 2019 novel coronavirus disease in Wuhan, China. J Obstet Gynaecol Res 2021;47:1344-52. [PubMed] [CrossRef]

23. Zhang P, Heyman T, Greechan M, Dygulska B, Al Sayyed F, Narula P, et al. Maternal, neonatal and placental characteristics of SARS-CoV-2 positive mothers. J Matern Fetal Neonatal Med 2021 Feb 28:1-9. Online ahead of print. [PubMed] [CrossRef]

24. Hudak ML. Consequences of the SARS-CoV-2 pandemic in the perinatal period. Curr Opin Pediatr 2021;33:181-7. [PubMed] [CrossRef]

This work is licensed under the Creative Commons Attribution-NonCommercial-NoDerivs 4.0 Unported (CC BY-NC-ND4.0) License. To view a copy of this license, visit http://creativecommons.org/licenses/by-nc-nd/4.0/ or send a letter to Creative Commons, PO Box 1866, Mountain View, CA 94042, USA.

Publisher's Note: The content of this publication does not necessarily reflect the views or policies of the publisher, nor does any mention of trade names, commercial products, or organizations imply endorsement by the publisher. Scientific and legal responsibilities of published manuscript belong to their author(s). The publisher remains neutral with regard to jurisdictional claims in published maps and institutional affiliations. 